\title{
Kuwaiti Teachers' Satisfaction with the Social Studies Curriculum and Their Performance in the Classroom
}

\author{
Abdullah J. Alhajri \\ Associate Professor, \\ CEI, Kuwait University, \\ Jamal Abdul Nasser St, Kuwait
}

DOI: https://doi.org/10.36941/jesr-2022-0028

\section{Abstract}

This study investigated Kuwaiti teachers' satisfaction with the structure of the social studies curriculum and their performance in the classroom. It aimed to answer two main questions through a twenty-two-item questionnaire applied to a sample of 132 social studies teachers. The results have shown moderate satisfaction in this regard among those teachers. There were no effects of teacher gender, experience, or various school districts on the satisfaction of social studies teachers and their performance in the classroom. The researcher called for reevaluating the curriculum by its developers to pinpoint and rid it of the causes that obstruct higher teachers' satisfaction and performance, mainly its inadequacy to students' interests, needs, skills, creativity, individual differences, and practical learning activities, and up-to-date teaching methods.

Keywords: Teachers' satisfaction, social studies, curriculum structure, teacher performance

\section{Introduction}

Job satisfaction received broad interest among many researchers who focused on investigating this topic to the fullest. That interest is not new, and research seems to have been carried out for many decades. However, that can be understood when we relate it to its role in any establishment's success, specifically when its employees see and sense that their needs are met. Zaim, Demir \& Budur (2020) argued that "employee performance might have a positive impact on employee satisfaction, which is, in turn, significantly related to company's long-term profit" (Cited by Zardasht, Omed \& Taha, 2020, p. 49). Varma (2017) indicated that the most critical factor that affects the business is its employees, and states that "if the employees of a business are motivated towards the organizational objective, the business can achieve its goals very easily" Varma, 2017, P.17).

This satisfaction is of great importance to the teacher, and once he is satisfied, we can expect flawless and generous giving capacity. As it does with every laborer in every job, there seems to be some research indicating the significance of job satisfaction to those working in the education profession, that is, the teachers. This has led Okeke and Mtyuda (2017) to report that teacher satisfaction is germane for social transformation sustainability (Okeke and Mtyuda, 2017, p, 65). As such, every individual teacher is undoubtedly apt to reach their optimum level of job performance 
and contribution to the wellness of their schooling establishment. Employees would stay at work only when their organization satisfies them (Zamanan, Alkhaldi, Almajroub, Alajmi, Alshammari \& Aburumman, 2020). Zardasht, Omed \& Taha make an allegation that "some of these employees want to change their jobs or workplaces due to several different reasons, some of which originate from their workplace or their manager or their monthly salary, and some other reasons" (Zardasht, Omed \& Taha, 2020, p. 54). That led Shibiti (2019) to point to the need for an empirical investigation of the relationship between retention factors and work engagement to facilitate employee retention.

Bota (2013) refers to teacher's satisfaction as "the desire to obtain something closely related to personal and professional interests, culminating in guaranteeing success." Furthermore, he indicates that it is strongly correlated with motivation (Bota, 2013, p. 634). Many teachers, according to (Mertler (2002), " are unwilling to perform well" when they are dissatisfied and that this will affect their students' learning (Mertler, 2002, p. 44).

Mostafa and Pal (2018) pointed that "students of teachers who are satisfied with their current job scored 15 points higher in science, on average than students with less-satisfied teachers" (Mostafa and Pal, 2018, p. 53). Zembylas \& Papanastasiou (2005) thus argued "the importance of job satisfaction and teacher empowerment in determining educational quality" and "the impact of overall job satisfaction on teachers' sense of empowerment. (Zembylas \& Papanastasiou, 2005, p. 435).

Unfortunately, many teachers leave the profession because they are dissatisfied with the job. Madigan \& Kim (2021) provided evidence that "both burnout and job satisfaction are related to teachers' intentions to quit that profession (Madigan \& Kim, 2021, p. 26). Many of these teachers even leave the profession during their early years of teaching. Carver-Thomas \& Darling-Hammond (2017) reported a high teacher attrition rate in schools of the USA ( $8 \%$ annually). They add that the number of teachers leaving each year accounts for close to $90 \%$ of annual teacher demand (Carver-Thomas \& Darling-Hammond, 2017, p, 1). Jahan \& Ahmed (2018) describe that issue as a result of teachers' loss of interest in this noble profession (Jahan \& Ahmed, 2018, p. 72). "The early few years of a teacher's career," according to Renbarger \& Davis (2019), "impact their later commitment" to the job and, thus, there is significant importance for the "initial supports" to be watched for where turnover is high (Renbarger \& Davis, 2019, p. 30).

Jahan \& Ahmed (2018) claim that "Understanding teachers' job satisfaction is of importance in educational research" (Jahan \& Ahmed, 2018, p. 72). In the same line, Pramono and Amalia's (2020) study claims that the teaching job can be satisfactory to the people working there when it is rewarding. They concluded their study by recommending that "all stakeholders pay more to their job satisfaction to support school learning success" (Pramono and Amalia, 2020, p. 118). That has led Alhawari (2019) to stress providing a supportive and comprehensive environment for the social studies teacher and pointed to the necessity of the teacher training programs. He claims that such training could equip the "teachers with the skills, information, and knowledge needed to fully carry out their teaching duties" (Alhawari, 2019, p. 50). This topic, then, must receive educators' attention on how teachers should deal with the curriculum while teaching their students.

Unfortunately, in the case of Kuwait, teacher satisfaction is under-researched (Aljassar \& Altammar, 2020. P. 365). Some research indicated that Kuwaiti teachers are showing a high degree of dissatisfaction with their profession (Al-yaseen \& Al-musaileem, 2013). Further research on this issue in this region that concentrates specifically on satisfaction related to the social studies curriculum is needed, and that constitutes the primary attention of the present research.

\section{Statement of the Problem}

The body of research literature has shown that teachers' satisfaction is essential for their positive classroom teaching contribution. It can provoke and alleviate the teachers' suffering and improve their performance. Some of this research pointed to many causes of teacher dissatisfaction that need to be confronted. For example, the interviews conducted by Mongkonthan (2021) showed that teachers in Thailand schools had and presented positive attitudes toward the curriculum 
(Mongkonthan, 2021, p. 8). However, this case does not apply in Kuwaiti schools. Al-yaseen \& Almusaileem (2013) and Tayeh (2013) have pointed to Kuwaiti teachers' dissatisfaction. In addition, AlMashaan (2003) indicated significant differences between the satisfaction of male and female Kuwaiti teachers, and Aldwailah's (2013) study has shown that the satisfaction of female teachers was higher than that of males.

To the present researcher's knowledge, research on teacher satisfaction of the social studies teachers with their curriculum in Kuwait's schools is very scarce. Such research is required and must be put under more researchers' consideration. The present study's primary concern is to examine teachers' satisfaction with their social studies curriculum and performance. The variables that may differentiate teachers of different gender, school district, and years of experience are considered. It is hoped that its results provide relevant suggestions.

\section{Significance of the Study}

The issue of teacher satisfaction with the curriculum and performance seems to have received the needed attention of researchers around the world. However, this was not the case in all countries of the globe. Zembylas \& Papanastasiou (2003) claim that "most international studies on teacher satisfaction were done in developed regions" (Zembylas \& Papanastasiou, 2003, p. 361). It has been poorly covered by researchers in the schools of Kuwait as well, unfortunately. That applies to research on teachers' satisfaction with the social studies curriculum and their performance, which is significant. However, research works that should bring the local researchers' attention to the issue in the area to lift the level of such Kuwaiti teachers' satisfaction to its highest appears to be insufficient and are very scarce. Therefore, attending this issue in Kuwaiti school is required.

The present study results are hoped to serve the educational community by arriving at the necessary recommendations for improving teachers' curriculum satisfaction and performance. Furthermore, this study is expected to open the gates for the Kuwaiti curriculum developers to benefit from its results and consider renovating the social studies' curriculum contents to become more satisfying to the people teaching in the classrooms.

\subsection{Study Terminologies and Definitions}

\subsubsection{Teacher Satisfaction}

According to Zembylas \& Papanastasiou (2005), there seems to be "no generally agreed-upon definition of teacher job satisfaction or of what constitutes teacher satisfaction" (Zembylas \& Papanastasiou, 2005, p. 435). However, some researchers such as Liu, Bellibaş \& Gümüş (2021) define it as "teacher job satisfaction refers to teachers' affective and cognitive reactions to their profession as well as to their current work environment" (Liu, Bellibaş \& Gümüş 2021, p. 3).

\subsubsection{Curriculum Structure}

Posner (1974) defines curriculum structure as "A series of intended learning outcomes organized into some structural arrangements."

\subsubsection{Teacher performance}

According to Sastrawijaya, Oktaviani, \& Hadi (2019), teacher performance is defined as a "measure of the teacher's ability level after experiencing a process within a certain period " (Sastrawijaya, Oktaviani, \& Hadi, 2019, p. 2). 


\subsection{Study objectives}

The background of this topic has boosted several research questions which the present study will aim at investigating. First, the present study examines teachers' satisfaction with the existing social studies curriculum and their performance in the classroom. In addition, the differences in this satisfaction between the teachers of various genders, school districts, and years of experience are examined.

\subsection{Study Questions}

This study aims to answer two questions, they are:

1. What is the Social Studies teachers' satisfaction level with the curriculum and their performance in the classroom?

2. Is there any significant difference in the satisfaction levels between Kuwaiti social studies teachers with their curriculum and their performance in the classroom that can be afflicted by the variables of their gender, school district, or years of experience?

\section{Literature Review}

Teacher satisfaction is one of the necessary enhancement factors of teachers' classroom performance, and the body of research shows a need for carefully attending to it. Toropova, Myrberg, and Johansson (2021) asserted such importance of teacher satisfaction and claim that it contributes to teacher well-being; their students feel better with satisfied and content teachers, making them more willing to offer higher instructional quality and better learning support for their students, and demonstrate more substantial job commitment (Toropova, Myrberg, and Johansson, 2021. P. 71). Renata, Wardiah \& Kristiawan (2018) support that and claim that "teachers who are satisfied with their work will improve their performance and will have a positive impact on improving the quality of education (Renata, Wardiah \& Kristiawan, 2018, P. 44). Dicke, Marsh, Parker, Riley \& Waldeyer (2020) also assert that teacher well-being is related to student achievement and "provide strong evidence for a strong link between job satisfaction in the working environment and disciplinary climate and student achievement, particularly for teachers irrespective of the country" (Dicke, Marsh, Parker, Riley \& Waldeyer, 2020, p. 25).

Nevertheless, research on this topic is still very scarce in many countries despite its worth and importance for social studies teachers. For example, Bolin (2014) reported that few studies are conducted on job satisfaction and even fewer in the educational field (Cited in Alhajri, 2021, p. 93). Moreover, most international studies on teacher satisfaction were done in developed regions (Zembylas \& Papanastasiou, 2003, p. 361). That led Sahito \& Vaisanen (2017) to complain of that as they indicated that "very few studies about job satisfaction and the factors affecting job satisfaction and dissatisfaction have been conducted in Pakistan overall, let alone in Pakistan's Sindh province" (Sahito \& Vaisanen, 2017, p. 7). Kuwait is not exempted. Aljassar \& Altammar (2020) have reported that its "teacher satisfaction is under-researched" (Aljassar \& Altammar, 2020. P. 365). That is also suggested by Alazmi \& Salem (2021), who claim that their study on teacher burnout is one of the first few studies that examined teacher burnout. Therefore, there is a need to fulfill literature for similar research in developing countries.

There also seems to be a lack of studies that attended to the satisfaction of the social studies teachers. Werang, Agung, and Agung (2017), in their research on social sciences, asserted that there is still a lack of studies on this topic among teachers in Indonesia, especially in the Merauke district context. They claimed that there is a need for the school principals to enhance teachers' organizational commitment and job performance to reduce teachers' job dissatisfaction (Werang, Agung, and Agung, 2017, p. 708). A 2011 national study found 3-5\% of language arts and social studies vacancies were considered difficult to fill (Cited in Miller. 2018, p. 55). 
According to Alhajri (2021), who conducted his study on a sample of 132 social studies teachers, "Teachers' satisfaction can affect their performance on the job either positively or negatively" (Alhajri, 2021, p. 93), and that means that it can reflect on the students' general performances. Nordin, Ahmad, Ibrahim, and Abu Libdeh (2019) claim that student achievement can be higher when taught by satisfied teachers (Nordin, Ahmad, Ibrahim, and Libdeh, 2019, p. 35). He, thus, invited scholars to unearth the factors that engender more significant levels of teacher satisfaction, and Shama (2018) called to encourage teachers to increase their job satisfaction level to help the institution accomplish its goals. Christopher (2014), on his part, recommended and asserted the necessity for encouraging the teacher through every available measure of motivation and raising their interest and confidence in the job (Christopher, 2014. P. 25).

Many research works attended to the sources of teachers' satisfaction or dissatisfaction. For example, Fandel (2007) reported that teachers of nearly all high school subject areas (science, math, English as a Second Language, etc.) had experienced attrition concerns with social studies and physical education being the exceptions (Cited in Blackburn, Bunchm, and Haynes, 2017, p. 5). Bouguessa \& Meddour (2019), as one of these works, pointed the psychological pressures and suggested getting rid of their sources and causes indicating that it can decrease the teacher's selfesteem. In addition, the authors also pointed to the importance of providing teachers with the necessary consultation services, which would help these teachers adapt to these pressures. (Bouguessa \& Meddour, 2019, p. 219).

In the words of Toropova, Myrberg, and Johansson (2020), "a number of longitudinal studies have found bi-directional relations between school-working conditions and teacher well-being" (Toropova, Myrberg, and Johansson, 2020, p. 90). The findings of Jahan \& Ahmed's research (2018) on Bangladesh's secondary schools pointed to such sources as the school management and administration and teacher benefits as being affecting their satisfaction either positively or negatively that it can strongly relate to their willingness to perform on the job (Jahan \& Ahmed, 2018, p.86). The findings of facts and data in the analysis of Suchyadi's (2018) study increasingly support the previous results when it points to "the existence of a strong relationship between the Principal Supervision on Job Satisfaction either directly or indirectly (Suchyadi, 2018, p. 28). Such administrative issues were also present in Okeke and Mtyuda's (2017) study, pointing to the lack of textbook resources and classroom overcrowdedness as such sources (Okeke and Mtyuda, 2017, p. 57). Toropova, Myrberg, and Johansson's (2020) study results associated school-working conditions, including teacher workload, teacher cooperation, and teacher perceptions of student discipline to teacher job satisfaction (Toropova, Myrberg, and Johansson, 2020, p. 74). Roch's (2019) analyses suggest that lower salaries and limited union memberships help drive these lower satisfaction levels. That lower salary was also noted in Escobedo \& Hernández's (2021) study, where the findings showed that "teachers are least satisfied with the factor on salary and compensation they receive as teachers (Escobedo \& Hernández, 2021, p. 48). Shahanasbeegam \& Sneha (2017), on their part, affirmed that the important motivational aspects that mainly influence the teachers are job security, social status and services, and salary (Shahanasbeegam \& Sneha, 2017, p. 6). Ferguson, Mang \& Frost (2017) point to workload, student behavior, professional relationships with other teachers and administration, societal attitudes towards teachers, and employment conditions as being amongst such sources leading to teacher dissatisfaction (Ferguson, Mang \& Frost, 2017, p. 69). Toropova (2020) reported that student discipline was more important as a source for teachers' job satisfaction. Metha (2012) refers to such factors as less work pressure, low supervision, and high job security that may be held responsible for this. Alhazmi (2012) points to satisfaction with the subject, the lack of salary, and promotion as teacher satisfaction sources. Zembylas (2003), referring to teacher salaries, claims that teachers are motivated to work in this profession by extrinsic rather than intrinsic motives. Velmurugan (2016) also discloses that to "attract efficient people towards teaching profession and to retain the committed teachers in the same profession, their job satisfaction level has to be improved by offering decent salary, convenient working time, providing necessary freedom and assistance for their professional growth, etc., thereby efficient teachers may be retained in the educational 
institutions for producing competent leaders for future India" (Velmurugan, 2016, p. 22).

Researchers have attended to the effect of the various variables on the existence of significant differences in teachers' satisfaction, and the relationship between teacher characteristics and his satisfaction has also been examined.

Shatyat's (2018) and Alsuwairi's (2019) studies show an effect for the variable of sex for the male on satisfaction job. In their research, Rao, Shailashri, Chaudhuri, \& Kumar (2019) reported that their findings showed "male teachers as having significant job satisfaction compared to female teachers, which are mainly associated with salary, promotion opportunity professional training, and other fringe benefits. (Rao, Shailashri, Chaudhuri, \& Kumar, 2019, p. 997). Toropova (2020) found that female teachers tended to have higher job satisfaction levels. His study also indicated that a relationship between teacher cooperation and job satisfaction was more pronounced for male teachers. In the meantime, Mostafa and Pal's (2018) study results contradicted these studies' results regarding the effect of the gender variable. This study showed "no consistent pattern in the relationship between teachers' gender and their level of satisfaction" (Mostafa and Pal, 2018, p. 21). Aldwailah (2013), for example, administered a study on a sample of 232 Kuwaiti secondary school teachers of different genders, specializations, and years of experience. The results have shown that female teachers differed significantly in their satisfaction compared to males. Perie and Baker (1997) also reported that female teachers had a higher level of satisfaction.

Furthermore, in Shaukat, Vishnumolakala \& Al Bustami's (2019) research work, female teachers exhibited higher-level job satisfaction. Gil-Flores (2017) claims that this is due to the traditional association between feminine roles and tasks involving caretaking and service, making women more likely than men to prefer caring professions and teaching. This researcher, thus, adds that "the variable of gender constitutes a good predictor of job satisfaction" when his study finds greater job satisfaction among female teachers (Gil-Flores, 2017, p. 21). On the other hand, Both Metha (2012) and Ahmad (2018) attended to such differences between males and females in job satisfaction but indicated that male teachers were higher than female teachers. Furthermore, Lemma (2017) also reported that male teachers are more satisfied than female teachers and that "male teachers retain in education sector than female teachers and which is affecting female participation in the education sector" (Lemma, 2017, p, 31).

However, other researchers did not indicate such differences that are related to teachers' gender. For example, Alhazmi's (2012), Zuraigat's (2013), Ch, Ahmad, Malik, \& Batool's (2017), Shama's (2018), Alreeh's (2018), and Alhawari's (2019) studies indicated no effect of teacher's sex. On the other hand, male teachers' satisfaction level was more minor in Abbas's (2016) and Sultana, Sarker \& Prodhan's (2017) research studies.

Other research examined the effect of the teachers' years of experience. Abbas (2012), as an example, confirmed the existence of differences between teachers' satisfaction related to this factor. However, here we notice contradictory findings, where Perie (1997) report that "public secondary teachers with three years of experience or less "tend to have higher levels of satisfaction than those of 4-9 years of experience, which in turn, are more likely to have high levels of satisfaction than those with 10-19 years of experience". He added that "Teachers with over 20 years of experience were the least satisfied in this study" (Perie, 1997, p. 19). On the other hand, Alhazmi (2012), Abbas (2016), Shatyat (2018), Alreeh (2018), Alsuwairi (2019), and Al-Hamid (2019) do not report any differences among teachers of different years of experience. Furthermore, regarding the satisfaction of social studies teachers, Habib's (2015) and Alsharaa's (2019) research has shown that the less experienced teachers of the social studies were more satisfied with their curriculum than their counterparts of longer experiences. Rao, Shailashri, Chaudhuri, \& Kumar's (2019) study also indicated no such significant difference among the three groups of teachers' teaching experiences (below ten years, 10 to 20 years, and above 21 years) (Rao, Shailashri, Chaudhuri, \& Kumar, 2019, p. 100o).

Zuraigat's (2013), Shatyat's (2018), and Al-Hamid's (2019) studies show an effect for the variable of high qualification on job satisfaction. Nevertheless, Alreeh's (2018) and Alsuwairi's (2019) studies showed no such differences due to the variables' effect of qualification. Metha's (2012) study results 
were concerned with the impact of the variable of the type of the school, and it showed that the government schoolteachers appeared more satisfied than the private school teachers.

Also, several other studies have been related to teachers' satisfaction with the curriculum. Brereton (2019), for example, listed 11 negative factors affecting teacher satisfaction in his study and pointed to the factors of rigidity of the curricula, content repetitiveness, and lack of intellectual challenge (Brereton, 2019, p. 259). In addition, Putwain \& von der Embse (2019) found that teachers perceived more significant pressure from imposed curriculum changes and experienced tremendous stress negative emotions. They claimed this could be due to uncertainty, stress, curriculum change, and self-efficacy surrounding the new curriculum (Putwain \& von der Embse, 2019, p. 11). Finally, in Abdelsalam, Rodriguez, \& Brallier's (2020) study, the teaching staff was only $40 \%$ more likely to be satisfied with the curriculum. The researchers think that this was because this staff thought of it helping develop thinking critically and solving problems.

Several Researchers paid attention to giving the necessary suggestions and recommendations on the topic. Al-Tuwaijriy (2014) called for the necessity of considering teachers' opinions as an essential factor for improving the curriculum (Al-Tuwaijriy, 2014, p. 29). Alshehry (2014) asserted that and pointed that "it is crucial to take teachers' points of view into consideration in the development of the curriculum," which would lead to "more devotion and commitment." Al-yassen \& Al-musaileem (2013) and Alsuwairi (2019) also called for a dialogue with teachers to involve them in decisionmaking and change to achieve their work satisfaction. Ellili-Cherif \& Hadba (2017) supported all of these calls as the researchers state that "for a curriculum to be implemented as intended, teachers should be involved in curriculum development. Teacher involvement in curriculum development can make it more effective since they are aware of the students' and their own needs" (Ellili-Cherif \& Hadba, 2017, P. 19). Shah (2016), in his study, noted that teachers are divided in their opinions about their curricular weightage and indicated that they were dissatisfied and complained about the shortages in the necessary teaching materials (Shah, 2016, p. 254). Song \& Mustafa (2015), in this regard, strongly suggest "providing more curriculum materials or extracurricular activities to teachers" (Song \& Mustafa 2015). Alreeh's (2018) research suggested improving the relationship between colleagues and their superiors. Song \& Mustafa (2015) recommended the provision of "more professional development opportunities" to teachers. Finally, Ali (2020) recommended courses that can develop positive trends towards the teaching profession. The results of Alhawari's (2019) study on a sample that consisted of 251 teachers from the Ministry of Education in Irbid governorates in Jordan pinpointed the importance of training programs for the development of their skills which would "stimulate them to interact" (Alhawari, 2019, p. 65).

In conclusion, the literature shows that many teachers leave the profession related to their job dissatisfaction, reflecting on their well-being and performance in the classroom. That is especially true in the still-developing countries, in general, and in the State of Kuwait specifically. Therefore, this topic of teacher satisfaction appears to be of great importance that it needs more attendance and care since it can positively or negatively reflect on the educational process.

\section{Research Methodology}

\subsection{Research Design}

The descriptive qualitative approach to collect data and describe sample social studies' teacher satisfaction with the social studies curriculum was used in this study. A 22 item-questionnaire was designed and administered to collect data from the study sample. This is the design that is most appropriate for this study.

\subsection{Data Collection Procedures and Study's Instrumentation}

The data collection procedure involved implementing a researcher-designed 22-item questionnaire 
about teachers' satisfaction with the social studies curriculum and their performance. This questionnaire used a 5-point scale:

\begin{tabular}{|c|c|c|c|c|}
\hline 5 & 4 & 3 & 2 & 1 \\
Very high & High & Moderate & Low & Very low \\
\hline
\end{tabular}

\subsection{Validity of the instrument}

The instrument construct validity was obtained after presenting the questionnaire to 6 colleagues, five from the Department of Curriculum and Instruction and another colleague from the Department of Educational Psychology in the College of Education at Kuwait University. Their observations that involved deleting, adding, and modifying the instrument were used to put it in its final form before its application. As a result, the scored correlation coefficient of the tool was .972 , which is statistically significant at $1 \%$, indicating a high internal consistency validity.

\subsection{Reliability of the instrument}

The researcher calculated the Alpha Cronbach coefficient to ensure the reliability of the study instrument. The general reliability score of (0.95) was very high, thus, indicating the reliability of results reached by the study.

\subsection{Study Sample}

One hundred thirty-two Kuwaiti social studies teachers participated in the present study (see Table1). The variables of their gender (Male \& Females), experience (Less than five years, 6-10 years, and over ten years), and school district (Capital, Mubarak Al-Kabeer, Farwaniyah, Jahra, Ahmadi, and Hawali) were considered. This sample was randomly chosen, and it consisted of teachers who willingly gave their opinions on the study questionnaire. In addition, a link to this questionnaire in Google Drive was distributed through various social media such as Whatsapp, myU, and Twitter. As such, the responses were electronically collected.

Table 1: Sample of the study

\begin{tabular}{|c|c|c|}
\hline \multirow[b]{2}{*}{ Gender } & Males & 54 \\
\hline & Females & 78 \\
\hline \multirow{6}{*}{ School district } & Capital & 36 \\
\hline & Mubarak Alkabeer & 19 \\
\hline & Farwaniyah & 23 \\
\hline & Jahraa & 22 \\
\hline & Ahmadi & 18 \\
\hline & Hawali & 14 \\
\hline \multirow{3}{*}{ Years of experience } & 1- 5 years & 55 \\
\hline & 6-10 years & 21 \\
\hline & Above 10 years & 42 \\
\hline Total & \multicolumn{2}{|c|}{132} \\
\hline
\end{tabular}

\section{Data Analysis}

An SPSS data analysis tool software was applied to analyze the quantitative data collected in the study instrument questionnaire to measure different teachers' genders, school districts, and years of experience satisfaction with the social studies curriculum. This data analysis involved calculating all sample responses' means and standard deviations. For example, testing the differences between social 
studies teachers of different genders was applied to calculate the T-values. Likewise, F-values were calculated by testing the differences between social studies teachers at various school districts and years of experience.

Table 2 shows the level of verification intervals for each response in the five-point Likert scale.

Table 2: Verification intervals for each of the five responses

\begin{tabular}{|c|c|c|l|}
\hline Likert Scale & Interval & Difference & Satisfaction Level \\
\hline 1 & $1.00-1.79$ & .79 & Very Low \\
\hline 2 & $1.80-2.59$ & .79 & Low \\
\hline 3 & $2.60-3.39$ & .79 & Moderate \\
\hline 4 & $3.40-4.19$ & .79 & High \\
\hline 5 & $4.20-5.00$ & .80 & Very High \\
\hline
\end{tabular}

\section{Study Results and Findings}

As guided by the study questions, the results are presented in Tables 3-7.

1. Results related to teacher satisfaction level with the social studies Curriculum and their performance in the classroom (Table-3 and 4 ).

The $1^{\text {st }}$ question of the present research work was stated as follows:

What is the Social Studies teachers' satisfaction level with the curriculum and their performance in the classroom?

Table 3: Means and standard deviations of responses on teacher satisfaction with the curriculum

\begin{tabular}{|c|c|}
\hline Mean & Standard Deviation \\
\hline 3.19 & 0.836 \\
\hline
\end{tabular}

Results presented in Tablez revealed that the Social Studies teachers' satisfaction with the Social Studies curriculum and classroom performance is "moderate." The mean of 3.19 of the sample's responses indicates a conservative, modest teacher satisfaction with the social studies curriculum.

Table 4: Means and standard deviation of items on teacher satisfaction with the curriculum

\begin{tabular}{|c|l|c|c|c|}
\hline$\#$ & Statement & Mean & S.D. & Rank \\
\hline 1 & Encourage students' creativity & 3.24 & 1.224 & 9 \\
\hline 2 & Attends to student differences & 3.11 & 1.110 & 13 \\
\hline 3 & Balances cognitive, psychomotor, and affective dimensions & 3.10 & 1.097 & 15 \\
\hline 4 & Attends to the fields' educational latest developments & 3.44 & 1.161 & 4 \\
\hline 5 & Attends to the necessity of students' participation in classroom activities & 2.97 & 1.241 & 19 \\
\hline 6 & Devoidness of inadequacy in its contents & 3.57 & 1.140 & 2 \\
\hline 7 & Content conformity to the students' interests & 3.50 & 1.156 & 3 \\
\hline 8 & Content conformity to the students' needs & 3.44 & 1.127 & 5 \\
\hline 9 & Contains appropriate the necessary illustrations & 2.59 & 1.223 & 22 \\
\hline 10 & Encourages students to resort to external learning activities & 3.41 & 1.284 & 7 \\
\hline 11 & Enhances the teachers' use of measures of evaluating students' acquired skills & 3.24 & 1.133 & 10 \\
\hline 12 & Invites teachers to utilize up to date teaching methods & 3.00 & 1.132 & 17 \\
\hline 13 & Abstains teachers' frequent use of traditional methods & 3.42 & 1.261 & 6 \\
\hline 14 & Sufficiently covers all subject matters & 3.25 & 1.194 & 8 \\
\hline 15 & Subject matters are appropriately related to each other & 2.84 & 1.145 & 21 \\
\hline 16 & Consists of both practical and theoretical learning activities & 3.11 & 1.082 & 14 \\
\hline 17 & Educational objectives are adequately clarified & 3.04 & 1.059 & 16 \\
\hline
\end{tabular}




\begin{tabular}{|c|l|c|c|c|}
\hline$\#$ & Statement & Mean & S.D. & Rank \\
\hline 18 & Relates to societal and environmental issues & 2.93 & 1.224 & 20 \\
\hline 19 & Attends to the daily current events & 3.17 & 1.182 & 12 \\
\hline 20 & Avoids any content limitations or shortages & 3.59 & 1.152 & 1 \\
\hline 21 & Encourages students to play roles on their sides & 2.98 & 1.182 & 18 \\
\hline 22 & Helps to build measures to evaluate student skills & 3.18 & 1.151 & 11 \\
\hline
\end{tabular}

Results presented in Table-4 revealed that all the 22 statement's means have ranged from 2.59 to 3.59. That means that the teachers' satisfaction with the social studies curriculum and, as such, with their performance was moderate on most of these items. Nevertheless, they showed "high teacher satisfaction" on seven of the item statements included in the questionnaire. These were items 20,6 , $7,4,8,13$, and 10, which ranked ahead of the remaining statements, which received "moderate teacher satisfaction."

2. Results associated to differences between teachers of different variables of gender, school district, and years of experience on teacher satisfaction with the curriculum and their performance in the classroom (Table-5).

The $2^{\text {nd }}$ question was stated:

Is there any significant difference in the satisfaction between Kuwaiti social studies teachers with their curriculum and their performance in the classroom that can be afflicted by the variables of teachers' gender, school district, or years of experience?

Firstly, Results related to differences between teachers of different genders on teacher satisfaction with the curriculum. (Table-5)

Table 5: Differences between the means according to the variable of gender

\begin{tabular}{|l|c|c|c|c|c|c|}
\hline Gender & $\mathrm{N}$ & Mean & SD. & T value & DF. & Sign. \\
\hline Males & 54 & 3.17 & .862 & \multirow{2}{*}{$\mathbf{0 . 2 4 3}$} & \multirow{2}{*}{$\mathbf{1 3 0}$} & $\mathbf{. 8 1}$ \\
\hline Females & 78 & 3.20 & .722 & & \\
\hline
\end{tabular}

The results show that the mean of male teachers was 3.17 (SD .862), and the female teachers' mean was 3.22 (SD .722). The T- value was -0.243, indicating no significant differences based on the gender variable at neither (o.01) nor at 0.05 levels.

Secondly, Results related to differences between teachers at various school districts on teacher satisfaction with the curriculum. (Table-6)

Table 6: Shows statistical analysis result of the differences between the means according to the variable of the school district

\begin{tabular}{|c|c|c|c|c|c|c|}
\hline School District & $\mathbf{N}$ & Mean & SD. & F Value & DF & Sig. \\
\hline Capital & 36 & 3.08 & .730 & \multirow{7}{*}{1.794} & \multirow{7}{*}{$5 / 126$} & \multirow{7}{*}{.12} \\
\hline Mubarak & 19 & 2.85 & .637 & & & \\
\hline Farwaniyah & 23 & $3 \cdot 51$ & .838 & & & \\
\hline Jahra & 22 & 3.29 & .796 & & & \\
\hline Ahmadi & 18 & 3.20 & 1.011 & & & \\
\hline Hawali & 14 & 3.13 & .673 & & & \\
\hline Total & 132 & 3.18 & .569 & & & \\
\hline
\end{tabular}

Table-6 represents the statistical analysis results of the study's data based on the variable of the school district. These results show no significant differences between teachers' satisfaction levels in the various school districts covered in this research. The F value of 1.794 was not significant at $1 \%$ level or $5 \%$ level.

Thirdly, Results related to teachers' different years of experience on teacher satisfaction with the 
curriculum. (Table-7)

Table 7: Results of the study's data based on the variable of teachers' years of experience

\begin{tabular}{|l|c|c|c|c|c|c|}
\hline Experience Years & $\mathbf{N}$ & Means & SD. & F value & df & Sig \\
\hline $1-5$ years & 55 & 3.08 & 0.844 & & & \\
\hline 6-10 years & 21 & 3.48 & 0.935 & 1.827 & $2 / 129$ & 0.17 \\
\hline Over 10 years & 56 & 3.19 & 0.776 & & & \\
\hline Total & 132 & 3.19 & 0.836 & & & \\
\hline
\end{tabular}

Table-7 represents the statistical analysis results of the study's data based on the variable of years of experience. The F value of 1.827 in this table indicates that teachers of different years of experience did not differ in their satisfaction. This value was not significant at any level, and this variable does not seem to differentiate the three groups of teachers. Beginning, mid-experienced, and lengthy experienced teachers' satisfaction with the social curriculum also appear identical.

\section{Discussion}

Unlike previous research conducted in other countries, the social studies curriculum appears moderately satisfying to Kuwaiti school teachers. On the other hand, they seem to be suffering from this curriculum, affecting their classroom performance. However, most mean scores recorded on the sample's responses to the questionnaire items showed "moderate satisfaction."

The result coincides with those of Brereton's (2019), Putwain \& von der Embse's (2019), and Abdelsalam, Rodriguez, \& Brallier's (2020) studies which indicated such level of satisfaction among teachers with the school curriculum.

Kuwaiti social studies teachers appear not content with the defects in their curriculum and its reflexing on their performance. The moderate means of teacher satisfaction shown in the results indicate that Social Studies teachers see some curriculum defects and deficits. This result supports, to some extent, Al-yaseen \& Al-musaileem's (2013) study findings which reported a high degree of dissatisfaction among Kuwaiti teachers. Among these defects and shortages are the curriculums' inadequacy to students' interests, needs, and skills. Its attendance to students' differences and creativity are neglected as well. That must be an alarming signal to its developers to reexamine its weaknesses and defects that downsized that satisfaction. Therefore, teachers' assessments of this curriculum must be attended to while approaching these defects as a first step towards renovating this curriculum. Alt-Tuwaijry (2014) stated this demand of considering teachers' suggestions to enhance the curriculum according to educational innovations.

Contrary to social studies teachers, the English language teachers in Kuwait's primary schools have a different picture. They hold high-moderate satisfactory levels towards the curriculum. This picture holds that these teachers highly rank their curriculum as enriching the whole educational system (Sadeq, Akbar, \& Al Wazzan, 2021). That affirms the need to revise the social studies curriculum by its developers and designers to meet the teachers' satisfaction, as does the English language curriculum. Overlooking these defects should not continue since it can be hindering the recent educational reforms from taking place in the schools of Kuwait.

Unfortunately, these curricula are prepared by the old traditional school of thought adherents attached to timeworn curriculum content forms. Those developers must be substituted with those ready to apply the latest education and curriculum development trends. Appointing based upon appeasement must not continue. Al-Mi'a (2017) and Al-Otaibi (2015) reported that old practices are still in effect, leading to the overall climate of teachers' dissatisfaction with the education quality. (Cited in Aljassar \& Altammar, 2020).

Although social studies are meant to pay attention to the "daily current events," we find it short in the ones structured for Kuwaiti schools. That is true for societal and environmental issues, which 
have no place in this curriculum. There is a need to pay serious attention to this essential role of the field. Also, there is a similar need to attend to a lack of practical learning activities or clarified educational objectives. The curriculum does not encourage the utilization of up-to-date teaching methods. On the contrary, it only suites traditional ones.

Zembylas \& Papanastasiou (2003) called for research on teachers' satisfaction in developing countries. Sources of satisfaction and dissatisfaction among teachers, according to Alhazmi (2012), vary between developed and developing countries. Kuwait is one of these developing countries. Reaching out for the sources of the teachers' dissatisfaction and ways to overcome them and suggest recommendations suitable for its renovation. This supports Bouguessa's (2019) point of the need to uncover the sources of teacher dissatisfaction. The more the teacher is satisfied with the curriculum, the more advantages will loom that process. Of course, the best way to do that is to consider involving the teacher in this process. Al-yassen \& Al-musaileem (2013), Al-Tuwaijriy (2014), Alshehry (2014), Ellili-Cherif \& Hadba (2017), and Alsuwairi (2019) all have suggested such teacher involvement.

The present research findings have shown that Kuwaiti social studies teachers of both male and female genders do not differ in their level of satisfaction with the curriculum. These results coincided with the findings of other research work such as those of Alhazmi (2012), Zuraigat (2013), Abbas (2016), Alreeh (2018), Shama (2018), Ahmad (2018), and Alhawari (2019). Nevertheless, at the same time, these results come in contradictory to other studies that affirmed the presence of such effects, such as Perie and Baker (1997), Metha (2012), Shtyat (2018), Alswairi (2019), and Toropova (2020). That might be attributed to the assumption that this research was conducted in developed regions, whereas the present study was operated in a developing one. This claim suggests more research to investigate such acknowledgment.

The Kuwait social studies teachers' satisfaction did not differ according to the school district. This lower satisfaction of teachers must bring its developers' attention to this issue and try to revise that curriculum to the degree that would bring about that will win teachers' satisfaction. The lesser than high satisfaction would negatively affect the teachers' performance and their students' learning process. The results for science teachers' satisfaction with their current job are similar and even more potent (Figure 5.11). That supports Mostafa and Pal's (2018) study results which have shown that "school students with teachers who are highly satisfied with their current job score 15 points higher in science, on average than students with less-satisfied teachers" (Mostafa and Pal, 2018, p. 53).

That agreement between teachers of all six school districts is so alarming. Sullanmaa, Pyhältö, Pietarinen, \& Soini (2019) emphasize the necessity of understanding the similarities and differences between the "perceptions of state- and district-level stakeholders" (Sullanmaa, Pyhältö, Pietarinen, \& Soini, 2019, p222)

The Kuwait social studies teachers' satisfaction also did not differ according to the Social Studies teachers' years of experience' variable. Therefore, it reaffirms the results of Alswairi's (2019) study on Kuwaiti schools. It also supports the findings of Alhazmi (2012), Zuraigat (2013), Shtyat (2018), Alreeh's (2018), and Al-hamid (2019). But these results did not coincide with Perie and Baker's (1997) findings which have indicated more satisfaction among teachers of low experiences; young teachers are higher in their satisfaction than older ones. Likewise, Habib's (2015) research study, Abbas's (2016) study, and alsharaa's (2019) study claimed such effects.

There appears to be a need to reach rational analysis in future research from one study to another. For example, it might be related to the different teacher preparation programs or the curriculum taught. More studies are needed to rationalize and shed some light on this fact. Song \& Mustafa (2015) and Alhawari (2019) have previously made such invitations.

\section{Conclusion and Recommendations}

The satisfaction of any employee in any institution is a critical component of its success in achieving and reaching its successful and fruitful accomplishment goals. Of course, this applies to the 
educational institutions as well in which its employees, specifically the teachers who are the asset for the achievement of every school ambition to deliver the proper education to its students and learners. Naturally, those teachers cannot give their best if the surrounding school circumstances are not appealing to them; mainly, we name the curriculum they deal with, which should be satisfying.

Unfortunately, the present study has shown that the Kuwaiti social studies teachers' satisfaction related to the social studies curriculum has not hit the upbeat target that every teacher hopes. On the contrary, teachers' satisfaction level was only moderate. It was not high enough to guarantee and maintain the wished-for form of educating our school students. That case was noticed for all teachers of both genders, school districts, and teachers of different years of experience.

These results should alarm us to reshape the social studies curriculum to benefit teachers' satisfaction, performance, and student learning. Thus, the researcher recommends that sincere efforts to revise, amend, alter, and develop the present curriculum must be considered. The appropriate people, the specialists, must do this task. They, indeed, can undoubtedly accomplish the mission well.

In addition, the researcher suggests conducting and attending further research to point out the causes obstructing higher teacher satisfaction with the curriculum. He also suggests future research that concerns itself with comparing Social Studies teacher satisfaction with the curriculum with that of other school subjects.

\section{Acknowledgment}

The author acknowledges the valuable assistance of Maha M. Alazemi, who is an undergraduate student at the college, for her efforts in helping with the processing of the related literature.

\section{References}

Abbas, M. (2016). Job satisfaction among the foundation stage teachers and its importance in the educational process: Local Khartoum model. (Unpublished Master's Thesis). International African University. (In Arabic). Khartoum, Republic of Sudan.

Abdelsalam, M., Rodriguez, T. E., \& Brallier, L. (2020). Student and faculty satisfaction with their dental curriculum in a dental college in Saudi Arabia. International journal of dentistry.

Ahmad, W. (2018). Elementary school teachers' job satisfaction and its relation to their organizational commitment in Omdurman. (Southern Countryside). (Unpublished Master's Thesis). Sudan University of Science and Technology. Omdurman, Sudan.

Alazmi, S. N., \& Salem, A. A. (2021). The Role of Emotional Regulation, Teacher Burnout, Personality Traits, \& Internet Addiction among Kuwaiti Teachers. North American Journal of Psychology, 23(3).

Aldwailah, A. (2013). Kuwaiti Secondary school teachers' satisfaction in the light of some variables. The Journal of Educational Sciences. (In Arabic). 21: (1, 1), 273-297.

Alhajri, Abdullah. (2021). Teachers' Satisfaction with Kuwaiti Social Studies Curriculum Effects on the Educational Process. International Journal of Humanities and Social. 11: (3), 91-107.

Al-hamid, A. (2019). The Effectiveness of teaching Fiqh through the SNIPS strategy on fifth-grade students' achievement, retention, and attitudes towards learning. (In Arabic). Saudi Journal of the educational sciences. (65): 147- 173 .

Alhawari, M. (2019). Degree of Satisfaction of Social Studies Teachers on the Reality of the Training Program "Towards a Supportive and Comprehensive Learning Environment for Public Schools in the First Directorate of Education in Irbid in Jordan," from their Perspective. International Journal of Innovation, Creativity, and Change. 6, (2), 48-67.

Alhazmi, F. (2016). A review of Teacher Job Satisfaction: An Annotated Bibliography. International Journal of Management and Marketing Academy. 1, (2), 100-105.

Ali, A. (2020). Some variables of trends towards work in the light of (age and experience) among sport education teachers. The Journal of Sports Sciences. (In Arabic). 40, (12), 1-17.

Aljassar, S., \& Altammar, J. (2020). A Framework for the Professional Development of in-Service Teachers in Kuwait. Journal of Turkish Science Education, 17(3), 364-386. 
Al-Mashaan, O. S. (2003). Comparison between Kuwaiti and Egyptian teachers in Type A behavior and job satisfaction: A cross-cultural study. Social Behavior and Personality: an international journal, 31(5), $523-533$.

Alreeh, G. (2018). Job Satisfaction of Teachers at Base Stage and its Impact on the Professional Performance Improvement. (Unpublished Master's Thesis). Sudan University of Science and technology. (In Arabic). Khartoum, Republic of Sudan.

Alsharaa, S. (2019). The degree of transparency in the relationship between high school principals and teachers and their impact on job satisfaction from their point of view in the Education Directorate of the Ramtha Brigade. (Unpublished Master's Thesis). (In Arabic). Al-albayt University. Almafraq, Jordan.

Alshehry, A. (2014). Investigating Factors Affecting Science Teachers' Performance and Satisfaction toward their Teaching Process at Najran University for Girls' Science Colleges. International Journal of Higher Education. ISSN 1927-6044: 3, (2), 73-82.

Alswairi, F. (2019). The role of strategic management of human resources in achieving job satisfaction for Alahmadi schools in government secondary schools in Alahmadi, State of Kuwait from teachers' perspectives. Journal of educational sciences. (In Arabic). 1, (2), 240- 280.

Al-tuwaijry, N. (2014). Evaluation of the enhanced Arabic curriculum for the first of elementary grade by teachers and instructors of Arabic in Kuwait. Journal of Arab Childhood, (In Arabic). 16. (61), 9-31.

Al-Yaseen, W. S., \& Al-Musaileem, M. Y. (2015). Teacher empowerment as an important component of job satisfaction: a comparative study of teachers' perspectives in Al-Farwaniya District, Kuwait. Compare: A journal of comparative and international education, 45(6), 863-885.

Blackburn, J. J., Bunchm, J. C., \& Haynes, J. C. (2017). Assessing the Relationship of Teacher Self-Efficacy, Job Satisfaction, and Perception of Work-Life Balance of Louisiana Agriculture Teachers. Journal of Agricultural Education, 58(1), 14-35.

Bota, O. (2013). Job satisfaction of teachers. $2^{\text {nd }}$ World Conference on Educational Technology Research. Social and Behavioral Sciences, 8: $634-638$.

Bouguessa, O., and Meddour, L. (2019) The level of psychological burnout among middle school teachers. Psychological and Educational Studies, (In Arabic), 12, (3), 196-211.

Brereton, P. (2019). Teacher perceptions of worGing within a strongly unified curriculum. New Directions in Teaching and Learning English Discussion, 7, 257-271.

Carver-Thomas, D., \& Darling-Hammond, L. (2017). Teacher Turnover: Why It Matters and What We Can Do About It. Learning Policy Institute.

Ch, A. H., Ahmad, S., Malik, M., \& Batool, A. (2017). Principals' Leadership Styles and Teachers' Job Satisfaction: A Correlation Study at Secondary Level. Bulletin of Education and Research, 39(3), 45-56.

Christopher, N. (2014). Factors influencing secondary school teachers' job satisfaction levels in Lang'ata District, Nairobi, Kenya Department of Education.: University of Eldoret. International Journal of Community and Cooperative Studies, 1, (2), 12-26.

Dicke, T., Marsh, H. W., Parker, P. D., Guo, J., Riley, P., \& Waldeyer, J. (2020). Job satisfaction of teachers and their principals in relation to climate and student achievement. Journal of Educational Psychology, 112(5), 1061.

Ellili-Cherif, M., \& Hadba, H. M. (2017). Fidelity to and satisfaction with prescribed curriculum in an Arab educational context: ESL teachers' perspective. The Curriculum Journal, 28(3), 367-388.

Escobedo, F., \& Hernández, R. M. (2021). Organizational climate and teacher satisfaction in the MyPes of the tumbes education sector. Turkish Journal of Physiotherapy and Rehabilitation, 32(2), 1573-1578.

Ferguson, K., Mang, C., \& Frost, L. (2017). Teacher stress and social support usage. Brock Education Journal, 26(2).

Gil-Flores, J. (2017). The role of personal characteristics and school characteristics in explaining teacher job satisfaction. Revista de Psicodidáctica (English ed.), 22(1), 16-22.

Habib, O. (2015). Calendar experience developing social studies curriculum for fourth grade from the first episode of primary education from teachers' viewpoint in the Syrian Arab Republic. (Unpublished Master's Thesis). Damascus University (In Arabic).

Jahan, M., and Ahmed, M. (2018). Teachers' Job Satisfaction: A Study in Secondary Schools of Bangladesh. Journal of Contemporary Teacher Education, II, (I), 71-91.

Kabilan, M. (2019). Malaysian English language teachers' satisfaction level of their professional development. English Language Teaching and Research, 1, (1), 49-59.

Lemma, S. M. M. S. (2017). The effect of gender and school climate on job satisfaction of Government Secondary School Teachers in Sidama Zone, Snnpr. Journal Of Humanities and Social Science. Volume 22, Issue 2, Ver. IV (Feb. 2017) PP 25-32.

Liu, Y., Bellibaş, M. Ş., \& Gümüş, S. (2021). The effect of instructional leadership and distributed leadership on teacher self-efficacy and job satisfaction: Mediating roles of supportive school culture and teacher collaboration. Educational Management Administration E Leadership, 49(3), 430-453. 
Madigan, D. J., \& Kim, L. E. (2021). Towards an understanding of teacher attrition: A meta-analysis of burnout, job satisfaction, and teachers' intentions to quit. Teaching and teacher education, 105, 103425.

Mertler, C. A. (2002). Job satisfaction and perception of motivation among middle and high school teachers. American secondary education, 43-53.

Metha, S. (2012). Job satisfaction among teachers. International Journal of Research in Commerce, IT $\mathcal{E}$ Management, 2 (4), 76-84.

Miller, C. M. (2018). Factors affecting job satisfaction and teacher retention for north Texas secondary science teachers. Dallas Baptist University.

Mongkonthan, S. (2021, July). Implementing the Earth System Science Curriculum in School through ResearchBased Learning and Technology Enhancing 21st Century Skills. In Journal of Physics: Conference Series (Vol. 1957, No. 1, p. 012026). IOP Publishing.

Mostafa, T. and Pal, J. (2018). Science teachers' satisfaction: Evidence from the PISA 2015 teacher survey. OECD Publishing, 168, (4), 1-93.

Nordin, M., Ahmad, T., Ibrahim, M., and Libdeh, E. (2019). Implementing Assessment Policy: Considering the Bifactor Teachers' Satisfaction Criterion. Universal Journal of Educational Research, 7, (10A), 35-41.

Okeke, C. I., \& Mtyuda, P. N. (2017). Teacher job dissatisfaction: Implications for teacher sustainability and social transformation. Journal of Teacher Education for Sustainability, 19(1), 54-68.

Perie, M. (1997). Job satisfaction among America's teachers: Effects of workplace conditions, background characteristics and teacher compensation. US Department of Education, Office of Educational Research and Improvement.

Perie, M. and Baker, D. (1997) National Center for Education Statistics: Statistical Analysis Report. Job Satisfaction Among America's Teachers: Effects of Workplace Conditions, Background Characteristics, and Teacher Compensation. US Department of Education Office of Educational Research and Improvement. The USA. http://www.ed.gov/NCES/.

Posner, G. J. (1974). The extensiveness of curriculum structure: A conceptual scheme. Review of Educational Research, 44(4), 401-407.

Pramono, R., and Amalia, S. (2020). Phenomenology Study of Teachers' Satisfaction at the State Junior High School. Jurnal Keguruan dan Ilmu Tarbiyah, 5 (1), 111-119.

Putwain, D. W., \& von der Embse, N. P. (2019). Teacher self-efficacy moderates the relations between imposed pressure from imposed curriculum changes and teacher stress. Educational Psychology, 39(1), 51-64.

Rao, M. A., Shailashri, V. T., Chaudhuri, M. S., \& Kumar, K. S. (2019). Job satisfaction among school teachers in Mangalore, Karnataka. A Journal of Composition Theory, XII, 990-1005.

Renata, R., Wardiah, D., \& Kristiawan, M. (2018). The Influence of Headmaster's Supervision and Achievement Motivation on Effective Teachers. International Journal of Scientific E Technology Research, 7(4), 44-49.

Renbarger, R., \& DAVIS, B. (2019). Mentors, self-efficacy, or professional development: Which mediate job satisfaction for new teachers? A regression examination. Journal of Teacher Education and Educators, 8(1), 21-34.

Roch, C. and Sai, N. (2016). Charter School Teacher Job Satisfaction. Educational Policy, 31, (7), 1-64.

Sadeq, T., Akbar, R., \& Al Wazzan, F. (2021). Competency-Based Curriculum (CBC) in Kuwait:" From the Ideal to Real." English Language Teaching, 14(1), 1-12.

Sahito, Z., \& Vaisanen, P. (2017). Factors affecting job satisfaction of teacher educators: Empirical evidence from the Universities of Sindh Province of Pakistan. Journal of Teacher Education and Educators, 6(1), 5-30.

Sastrawijaya, Y., Oktaviani, V., \& Hadi, R. (2019, December). The effect of problem development training using Moodle on teacher performance in developing problem tests in high school. In Journal of Physics: Conference Series (Vol. 1402, No. 7, p. o77069). IOP Publishing.

Shama, F. (2019). The Extent of Job Satisfaction among teachers in governmental Arab schools within the Greenline. (In Arabic). Journal of educational and Psychological Sciences, 27, (5), 459-467.

Shah, R. (2016). Teachers' Opinions on the Adequacy and Relevancy of Primary Education Curriculum. International Journal of Advanced Research and Innovative Ideas in Education, 2, (2), 246-256.

Shahanasbeegam, P.\& Sneha, E. (2017). Job satisfaction of women teachers with special reference to Malappuram district. International Journal of Human Resources Management (IJHRM), 6(6), 1-8.

Shaukat, S., Vishnumolakala, V. R., \& Al Bustami, G. (2019). The impact of teachers' characteristics on their selfefficacy and job satisfaction: A perspective from teachers engaging students with disabilities. Journal of Research in Special Educational Needs, 19(1), 68-76.

Shibiti, R. (2020). Public school teachers' satisfaction with retention factors in relation to work engagement. $S A$ Journal of Industrial Psychology, 46, (o), 1-9.

Song, S., \& Mustafa, M. (2015). Factors Impacting on Teachers' Job Satisfaction Related to Science Teaching: A Mixed Methods Study. Science Education International, 26(3), 358-375. 
Suchyadi, Y. (2018). Relationship between principal supervision in increasing the job satisfaction of private junior high school teachers in east Bogor district. Jhss (Journal of Humanities and Social Studies), 2(1), 26-29.

Sullanmaa, J., Pyhältö, K., Pietarinen, J., \& Soini, T. (2019). Differences in state-and district-level stakeholders' perceptions of curriculum coherence and school impact in national curriculum reform. Journal of Educational Administration. 210- 226.

Sultana, A., Sarker, M. N. I., \& Prodhan, A. S. (2017). Job satisfaction of public and private primary school teachers of Bogra District in Bangladesh. Journal of Sociology and Anthropology, 1(1), 41-46.

Tayeh, R. (2013). Teachers stress in public high schools in Kuwait (Doctoral dissertation, The University of Nebraska-Lincoln).

Toropova, A., Myrberg, E. and Johansson, S. (2021). Teacher job satisfaction: the importance of school-working conditions and teacher characteristics. Educational Review, 1-27. DOI.org/10.1080/oo131911.2019.1705247.

Varma, C. (2017). Importance of employee motivation \& job satisfaction for organizational performance. International journal of social science $\mathcal{E}$ interdisciplinary research, 6(2).

Velmurugan, R. (2016). Job Satisfaction of Teachers. Journal of Research in Humanities and Social Sciences, 9, (10). $20-23$.

Werang, B. R., Agung, A. A. G., \& Agung, G. (2017). Teachers' job satisfaction, organizational commitment, and performance in Indonesia: A study from Merauke District, Papua. International Journal of Development and Sustainability, 6(8), 700-711.

Zamanan, M., Alkhaldi, M., Almajroub, A., Alajmi, A., Alshammari, J., \& Aburumman, O. (2020). The influence of HRM practices and employees' satisfaction on intention to leave. Management Science Letters, $10(8)$, 1887-1894.

Zardasht, P., Omed, S., \& Taha, S. (2020). Importance of HRM policies on employee job satisfaction. Black Sea Journal of Management and Marketing, 1(1), 49-57.

Zembylas, M., \& Papanastasiou, E. (2003). Job satisfaction among school teachers in Cyprus. Journal of Educational Administration. 42, (3). $357-374$.

Zembylas, M., \& Papanastasiou, E. C. (2005). Modeling teachers empower

ment: The role of job satisfaction. Educational Research and Evaluation, 11(5), 433-459.

Zembylas, M., \& Papanastasiou, E. (2006). Sources of job satisfaction and dissatisfaction in Cyprus. British Association for International and Comparative Education, 36 (2), 229-247.

Zuraigat, H. (2013). Teachers' attitudes towards elements of Jordan's secondary social studies curriculum. (Unpublished Master's Thesis). Azhari Leader University. (In Arabic). Khartoum, Republic of Sudan.

Appendix 1: The study questionnaire

\begin{tabular}{|c|c|c|c|c|c|c|}
\hline Item\# & Statement & $\begin{array}{c}5 \\
\text { VSatisfied }\end{array}$ & $\begin{array}{c}4 \\
\text { Satisfied } \\
\end{array}$ & $\begin{array}{c}3 \\
\text { Neutral }\end{array}$ & \begin{tabular}{c|}
2 \\
Unsatisfied \\
\end{tabular} & $\begin{array}{c}1 \\
\text { VUnsatisfied }\end{array}$ \\
\hline 1 & Encourage students' creativity & & & & & \\
\hline 2 & Attends to student differences & & & & & \\
\hline 3 & Balances cognitive, psychomotor, and affective dimensions & & & & & \\
\hline 4 & Attends to the fields' educational latest developments & & & & & \\
\hline 5 & Attends to the necessity of students' participation in classroom activities & & & & & \\
\hline 6 & devoidness of inadequacy in its contents & & & & & \\
\hline 7 & Content conformity to the students' interests & & & & & \\
\hline 8 & Content conformity to the students' needs & & & & & \\
\hline 9 & Contains appropriate the necessary illustrations & & & & & \\
\hline 10 & Encourages students to resort to external learning activities & & & & & \\
\hline 11 & $\begin{array}{l}\text { Enhances the teachers' use of measures of evaluating students' } \\
\text { acquired skills }\end{array}$ & & & & & \\
\hline 12 & Invites teachers to utilize up to date teaching methods & & & & & \\
\hline 13 & Abstains teachers' frequent use of traditional methods & & & & & \\
\hline 14 & Sufficiently covers all subject matters & & & & & \\
\hline 15 & Subject matters are appropriately related to each other & & & & & \\
\hline 16 & Consist of both practical and theoretical learning activities & & & & & \\
\hline 17 & Educational objectives are adequately clarified & & & & & \\
\hline 18 & Relates to societal and environmental issues & & & & & \\
\hline 19 & Attends to the daily current events & & & & & \\
\hline 20 & Avoids any content limitations or shortages & & & & & \\
\hline 21 & Encourages students to play roles on their sides & & & & & \\
\hline 22 & Helps to build measures to evaluate student skills & & & & & \\
\hline
\end{tabular}

